\title{
Pretty But Somewhat Smelly
}

\author{
Archibald C. Budd, Swift Current, Sask.
}

Director S.N.H.S.

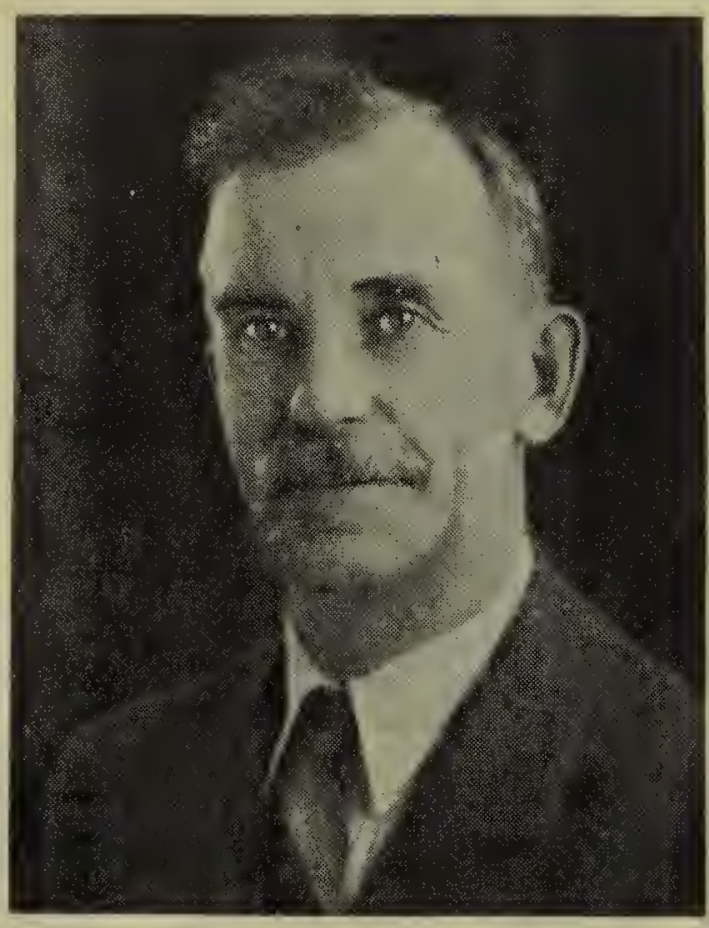

A while back I wrote of the Gumbo Evening-primrose, our sweetest smelling plant We might this time consider a rather unpleasantly scented species, the Spiderflower. It has been given several common names and also several scientific ones. We find it called Rocky mountain Bee-plant, Stinking-clover, Pink Cleome and Indianpink, also Cleome serrulata, the generally accepted name, Cleome integrifolia and Peritorna serrulatum. Nevertheless it has an odour all its own, but makes amends for it by its beauty.

Spider-flower grows from 1 to $2 \frac{1}{2}$ feet high, is very branching and has leaves bearing three lanceolate leaflets from 1 to 3 inches long. The flowers are pink or sometimes white with four sepals and four petals, with six stamens which protude considerably beyond the petals and give a fuzzy appearance to the inflorescence. The seed pods are from 1 to 2 inches long and contain a single row of rather large seeds. These pods are on a short stalk which extends above the flower and often the rernains of the petals and sepals can be seen at the joint on the stalk.

On the virgin prairies this was a plant of disturbed light soil, rodent mounds, animal trails in $s$ andy soils and such locations, but with the advance of settlement it finds many very favourable sites, roadside cuts, shoulders of grades, railway grades and so on. Frequently, in the southern part of the province, it will form a low, pretty hedge for miles along the roadside and seems to thrive in the drier and dustier areas. As one of its names implies, it is a good source of bee food in spite of its odour. At one time $\mathbf{I}$ understand a move was made to use the seeds for oil extraction but apparently the character-

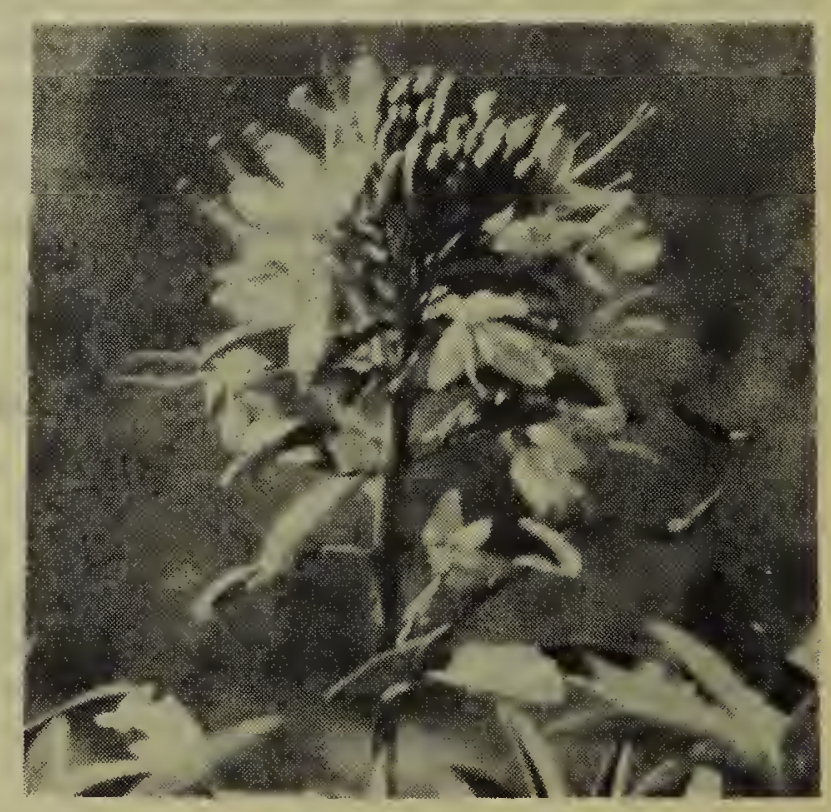

(continued on page 31 ) 
located a cardboard box and placing the bird inside began to look about for some string to tie it shut. Seeing none, I decided to turn the box upside down. In doing so the bottom fell out and only narrowly did I escape getting struck in the eye by its sharp beak before recapturing it. Just then the farmer returned home and after showing him the bird, remarked, "You did well to get that fellow, must be the one that's getting my chickens". Swallowing hard, I explained that this was a Heron, not a Hawk. Arriving back in town'I dropped the bird, still in the box, at the office. Returning a few moments later, I was surprised to see every available article, including a chair, atop the box. It seems that a Bittern, more feathers than flesh, can escape through any opening that will allow the neck and one leg to be thrust through. The bird was released wearing a band at a suitable slough.

From my kitchen window I have a string running to an ordinary droptrap, 3 feet by 4 feet and 7 inches deep. This was one of my first traps. Having been used for several years, it caught over 2500 birds, it lacked a few repairs. Accidently, one day during my absence, it was tripped and remained so until my return that evening, My wife questioned me then, as to why 1 had left two birds in it. I said I hadn't. Then she explained she had released them. Examing the trap I found two small birds still in it. Being more puzzled, I noticed a small hole near the center of the trap, barely an inch in diameter and directly over the edge of the pan of water supplied from a water drip pail above. Knowing the birds had entered the trap through the small hole to get the water, I enlarged the hole to two inches square. From August lst to August 28th, this trap had taken nearly 400 Warblers, all having entered through this small hole. Nearly 300 of these Tennessee Warblers. The remainder being made up of the following species; Black \& White, Nashville, Capemay, Myrtle, Chestnut-sided, Bay-breasted, Palm. Mourning, and Redstarts. Incidently the nearly 300 Tennessees banded during this period are more than the average banded yearly by all banders together in North America. All this by a trap accidently tripped, and a small hole.

\section{Blue Hurons - (continued from page 6)}

The young are comical looking with their long legs and big bills. When angered, they look quite fierce, stretching long necks and raising the feathers on top of their heads. till it stands straight up. They don't hesitate to strike at your either and are quite capable of giving you a nasty peck.

When we left the trees that harboured the colony we came out on a beautiful flat and there stood at least fifty Blue Herons -- a sight that is worth travelling a long distance to behold.

Alone the Byways -

\section{(continued from page 20)}

grasshoppers, it almost stepped in front of the car, but swerved in time. There was a hasty retreat to the wheat field.

In the spring we noticed a number of jack rabbits walking rather than hopping about in the fields, It was an action we hadnever seen before. They seemed to be searching carefully for something as each would stop trom time to time and then proceed. When mentioning this to a friend later, he spoke of a rumor that at this time of year the males go on such walks in search of young rabbits to destroy them. Does anyone have further information on this theory?
Sunsets along these by ways were brilliant or dull according to the cloud formations. They were al ways something to watch with an uninterrupted view as we came back to town. The speedy passing of the weeks was cause for lamentation that all too soon such rides would be over until another year.

Pretty But Somewhat Sinelly (continued from page 14)

istic smell remained. Spider-flower belongs to the Capparidaceae or Caper fanily, in which family is the Caper used to make sauce for mutton. Incidentally, when I was a youngster we made our caper sauce from Nasturtium seeds and used their leaves in sandwiches. 